\title{
Rat bite ulcer in an insensate foot
}

\author{
Kush Dev Jarial, ${ }^{1}$ Suja Sukumar, ${ }^{1}$ Anil Bhansali ${ }^{1,2}$
}

'Department of Endocrinology, Post Graduate Institute of Medical Education and Research, Chandigarh, India ${ }^{2}$ Post Graduate Institute of Medical Education and Research, Chandigarh, India

\section{Correspondence to} Dr Anil Bhansali, anilbhansaliendocrine@gmail. com

Accepted 5 September 2016

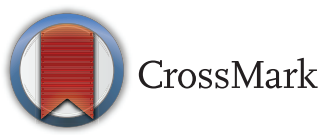

To cite: Jarial $K D$, Sukumar S, Bhansali A. BMJ Case Rep Published online: [please include Day Month Year] doi:10.1136/bcr-2016217294

\section{DESCRIPTION}

A 60-year-old man, a known case of type 2 diabetes mellitus for the past 20 years noticed sudden development of an ulcer on the plantar aspect of both
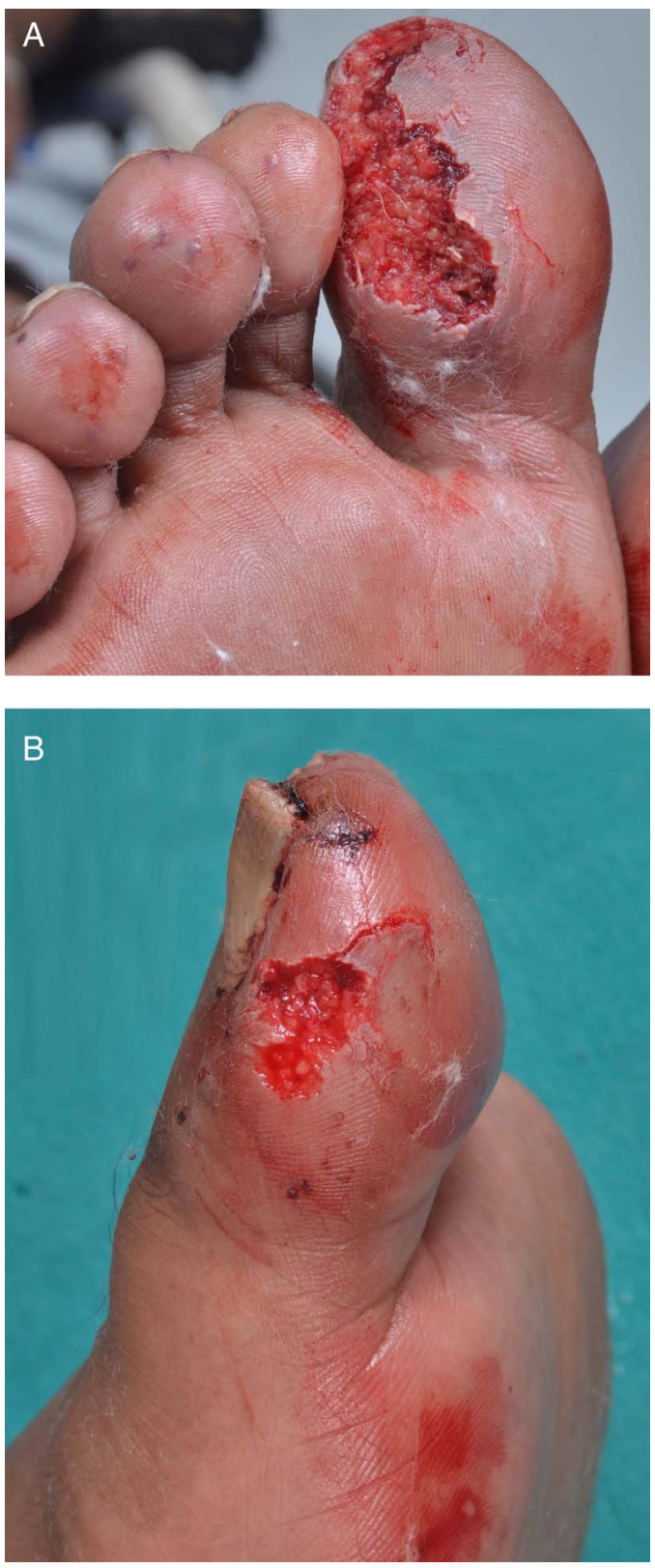

Figure 1 (A) Ulcer on right great toe (size $3 \times 2 \mathrm{~cm}$ ) which is bright red with irregular see-saw margins suggestive of gnawing by rat. (B) Ulcer on left great toe (size $1.5 \times 1 \mathrm{~cm}$ ) with irregular see-saw margins. great toes on waking up in the morning. The patient had examined his feet the previous night and it was free from any fissures, callosities or ulcers. There was no previous history of diabetic foot ulcer. The ulcer on right great toe was $3 \times 2 \mathrm{~cm}$, and on left great toe $1.5 \times 1 \mathrm{~cm}$, bright red, bleeding from the base with irregular see-saw margins suggestive of gnawing by a rat (figure 1A, B). The patient was on basal-bolus insulin therapy and oral hypoglycaemic agents with glycated haemoglobin of $9.4 \%$, suggestive of poor glycaemic control. On examination, he had severe sensory neuropathy as evidenced by loss of pain and touch sensations up to the knee joint, absent ankle reflex, positive Semmes-Weinstein $10 \mathrm{~g}$ monofilament test and vibration perception threshold of $>50 \mathrm{mV}(\mathrm{N}<25)$ on biothesiometry. All the peripheral pulses were palpable and the ankle-brachial index was 1.1 in both feet. He was treated with tetanus toxoid injection, cleaning and dressing and oral coamoxiclav.

Rat bite ulcers are not uncommon in patients with insensate foot, but often a misdiagnosed cause of foot ulcers. A history of sudden onset, painless fresh ulcers over digits in a setting of severe sensory neuropathy should raise a suspicion of rat bite as a possible cause. ${ }^{1}$

\section{Learning points}

Rat bite ulcers are not uncommon in patients with insensate foot, but often a misdiagnosed cause of foot ulcers.

- A history of sudden onset, painless fresh ulcers over digits in a setting of severe sensory neuropathy should raise a suspicion of rat bite as a possible cause.

Contributors KDJ prepared the manuscript and managed the patient. SS edited the manuscript and helped in patient management. $A B$ identified the case and guided the clinical management.

Competing interests None declared.

Patient consent Obtained.

Provenance and peer review Not commissioned; externally peer reviewed.

\section{REFERENCE}

1 Kalra B, Kalra S, Chatley G, et al. Rat bite as a cause of diabetic foot ulcer-a series of eight cases. Diabetologia 2006;49:1452-3. 
Copyright 2016 BMJ Publishing Group. All rights reserved. For permission to reuse any of this content visit http://group.bmj.com/group/rights-licensing/permissions.

BMJ Case Report Fellows may re-use this article for personal use and teaching without any further permission.

Become a Fellow of BMJ Case Reports today and you can:

- Submit as many cases as you like

- Enjoy fast sympathetic peer review and rapid publication of accepted articles

- Access all the published articles

- Re-use any of the published material for personal use and teaching without further permission

For information on Institutional Fellowships contact consortiasales@bmjgroup.com

Visit casereports.bmj.com for more articles like this and to become a Fellow 